\title{
울산신항의 파랑을 이용한 항만공사 작업일수 산정방법 연구 A Study on the Method of Calculating the Number of Working Days for Harbor Construction using the Wave of Ulsan New Port
}

\author{
백종대* · 정원무** . 이종인*** · 최혁진**** · 김미경***** \\ Jong-Dai Back*, Weon-Mu Jeong**, Jong-In Lee***, Hyuk-Jin Choi**** and Mee-kyung Kim*****
}

요 지 : 본 연구는 항만건설 시 파랑의 영향을 많이 받는 동해안의 울산신항을 대상으로 2020년 해양수산부에서 제시한 파랑출현율에 의한 비작업일수 산정방법의 적정성을 검토하고 개선방법을 제안하기 위해서 수행하였다. 이를 위해서 울산신항 남방파제 2-1공구 축조공사 시의 공사일지를 수집하였으며, JMA-MSM 바람장을 이용하여 2010년 에서 2019년까지 10년간의 고정밀 후측파랑 추산자료를 생성하였다. 파랑 추산자료는 WINK에서 제공하는 품질관 리된 울산부이와 울산신항 파랑 관측자료를 이용하여 정확도를 검증한 결과 결정계수 $\left(R^{2}\right)$ 가 0.96과 0.95 로 정도 높 게 산정되었다. 2015년 1월 1일부터 12월 31일까지 수행한 주요공정인 지반개량공(DCM)을 대상으로 공사일지를 분 석한 결과 파랑에 의한 비작업일수는 43일로 나타났다. 본 연구에서 제안하는 일별 작업한계 파랑조건을 적용한 경 우 48일로 산정되어 공사일지 대비 5 일 차이가 발생하였다. 하지만 차이가 발생한 5 일의 경우 2 일은 피항, 2 일은 작 업 대기 등으로 작업을 거의 못한 것으로 나타나, 본 연구에서 제안하는 일별 작업제한 파랑조건을 적용한 방법의 정확도가 높은 것으로 판단되었다. 최종적으로 2010년에서 2019년까지 10년간의 후측파랑 추산자료를 이용하여 일 별 작업제안 파랑조건으로 산정한 비작업일수는 39 일로 계산되었다. 이는 기존의 파랑출현율에 의한 방법으로 산정 된 28일에 비해서 11 일 많게 산정된 것이다.

핵심용어 : 바람장, 후측파랑 추산자료, 파랑 관측자료, 항만건설, 비작업일수

\begin{abstract}
This paper is about to review the propriety of the method for calculating the number of non-working days based on the wave appearance rate proposed by the Ministry of Oceans and Fisheries in 2020, and to propose an improved method for the Ulsan New Port on the East Sea which is greatly affected by waves during port construction. To this end, the construction daily reports of Ulsan New Port southern breakwater section 2-1 have been analysed and the high-precision wave hindcasting data for 10 years from 2010 to 2019 using the JMA-MSM wind field are generated. As a result of the accuracy of the wave hindcasting data using the quality-controlled Ulsan buoy and Ulsan New Port wave observation data provided by WINK, the coefficient of determination $\left(R^{2}\right)$ is as high as 0.96 and 0.95 . According to an analysis of the construction daily reports for the deep cement mixing method (DCM), a major process performed from January 1 to December 31, 2015, the number of non-working days due to wave is 43 days. When the daily work limiting wave condition proposed in this study is applied, it is calculated as 48 days, resulting in a difference of 5 days from the construction daily reports. However, in the case of the 5 days when the difference occurred, 2 days was little worked for the escape and 2 days was not worked for the waiting. It is inferred that the accuracy of the method to which this daily work limiting wave condition proposed in this study is applied is very high. Finally, the number of non-working days calculated as the daily work limiting wave condition is calculated as 39 days, using the wave hindcasting data for 10 years from 2010 to 2019. This is 11 days more than the 28 days calculated by the wave appearance rate method.
\end{abstract}

Keywords : wind field, wave hindcasting data, wave observation data, port construction, non-working day

*(주)해안해양기술 상무(Corresponding author: Jong-Dai Back, Senior Engineer, Coast and Ocean Technology Research Institute, A-2511 Hyundai Knowledge Industrial Center, 70 Dusan-ro Geumcheon-gu, Seoul 08584, Korea, Tel: +82-2-2104-6602, Fax: +82-2-2104-6601, bjd0409@cotri.co.kr)

**한국해양과학기술원 해양ICT융합연구센터 책임연구원(Principal Research Scientist, Maritime ICT R\&D Center, Korea Institute of Ocean Science and Technology)

***전남대학교 공과대학 토목공학과 교수(Professor, Department of Civil Engineering, Chonnam National University)

****(주)해안해양기술 대표(Chief Executive Officer, Coast and Ocean Technology Research Institute)

*****한국해양과학기술원 해양ICT융합연구센터 선임기술원(Senior Research Specialist, Maritime ICT R\&D Center, Korea Institute of Ocean Science and Technology) 


\section{1. 서 론}

우리나라는 한반도로 일컬으며 삼면이 바다로 둘러싸여 있 어 31개 무역항과 29개 연안항 및 수많은 국가어항과 지방 어항 등의 개발 및 유지관리를 위한 해상 건설사업이 상시 시 행 중에 있으며, 최근에는 해안침식피해에 따른 연안정비사 업 등도 동해안을 중심으로 활발하게 진행되고 있는 실정이 다. 또한, 우리나라 남해안과 서해안은 도서 및 육지지형에 의 해 외해 파랑에너지가 저감 되어 전파되고 해저경사가 비교 적 완만한데 비해서 동해안은 외해에 열려있고 해저경사가 급 해 하계 태풍과 동계 폭풍파에 의한 고파랑이 상시 내습하는 악조건의 해역 특성을 가지고 있어 해상 건설공사에 있어 파 랑을 고려한 작업일수 산정이 반드시 필요하다.

그러나 최근까지도 해상 건설공사에 적용되고 있는 작업일 수 산정은 약 50년 전에 제안된 기상현상에 의한 작업한계 를 고려한 산정방법(Ro, 1969)을 이용하여 왔으며, 이는 파 랑 등의 해상여건이 고려되지 않은 방법이다. 이에 해양수산 부에서는 작업환경이 열악한 해상공사의 특성을 감안하여 파 랑 등의 해상여건을 고려한 작업일수 산정방식을 새롭게 제 시하였다(Ministry of Oceans and Fisheries, 2020). 최근 서 해의 새만금 신항만 방파제 1단계 2공구를 대상으로 공사일 지 분석과 장기 후측파랑 추산자료를 이용하여 파랑을 고려 한 해상작업일수(Choi et al., 2019)를 검토한 바 있으나, 파랑 의 영향이 큰 동해안을 대상으로 해상작업일수를 연구한 사 례는 없는 것으로 조사되었다.

본 연구에서는 기존 방파제 보강 및 신규 방파제를 지속적 으로 건설하고 있는 동해안의 울산신항을 연구대상지로 설정 하고 2017년 완공된 울산신항 남방파제 2-1공구의 공사일지 를 수집하였으며, 울산해역을 대상으로 2010년부터 2019년 까지 10 년간의 장기 후측파랑 추산자료를 생성하였다(Fig. 1 참조). 후측파랑 추산실험의 바람장은 공간해상도(약 $5 \mathrm{~km}$ 해
상도) 및 2019년 전국 심해설계파 산출과제에서 태풍파 추산 의 재현성이 우수하게 평가된 JMA-MSM(일본 기상청) 예보 바람장을 수집하여 사용하였으며(Ministry of Oceans and Fisheries, 2019), 파랑추산의 정밀도를 높이기 위해서 수치모 형인 SWAN의 Nesting 기법을 적용하여 전해역(약 $5 \mathrm{~km}$ 해 상도)과 상세역(약 $100 \mathrm{~m}$ 해상도)을 연계하여 수행하였다. 장 기 후측파랑 추산자료의 재현성을 검증하기 위해서 해양수산 부에서 일반에 공개한 전국파랑 관측자료 제공시스템(Wave Information Network of Korea; WINK)에서 제공하는 품질 관리(Quality Control; QC)된 울산신항 인근의 울산(KMA, 기상청)과 울산신항(MOF, 해양수산부) 파랑 관측자료(Jeong et al., 2018)를 수집하여 검증에 사용하였다.

본 연구에서는 이와 같이 파랑 관측자료와의 검증을 통해 서 재현성을 확보한 후측파랑 추산자료와 울산신항 남방파제 2-1공구의 해상 건설공사의 주공정인 지반개량공 $(\mathrm{DCM})$ 을 시 행한 2015년 1 년간의 공사일지를 파랑에 의한 작업제한조건 (유의파고 $1.5 \mathrm{~m}$ 이상 또는 유의파고 $1.0 \sim 1.5 \mathrm{~m}$ 와 주기 8.0 초 이상)을 적용하여 비교, 분석을 수행하고 최종적으로 2020년 해양수산부에서 발간한 “항만건설공사 설계실무요령"에서 제 시한 항만건설공사 작업일수 산정방법을 사용한 파랑에 의한 비작업일수의 적정성 검토 및 개선방안을 제시하였다.

\section{2. 기존 해상 건설공사 작업일수 산정방법 검토}

본 연구에서는 항만건설공사에 있어 파랑의 영향을 많이 받 는 동해안을 대상으로 기존의 파랑을 고려한 해상 건설공사 작업일수 산정방법을 검토하고 개선방법을 제안하기 위해서 대규모 항만공사가 지속적으로 실시되고 있는 울산신항을 연 구대상지로 설정하였다. 이에 가장 최근인 2017년 9월 27일 준공한 “울산신항 남방파제(2-1공구) 축조공사 실시설계” 보 고서(Ulsan Regional Office of Oceans and Fisheries, 2013)
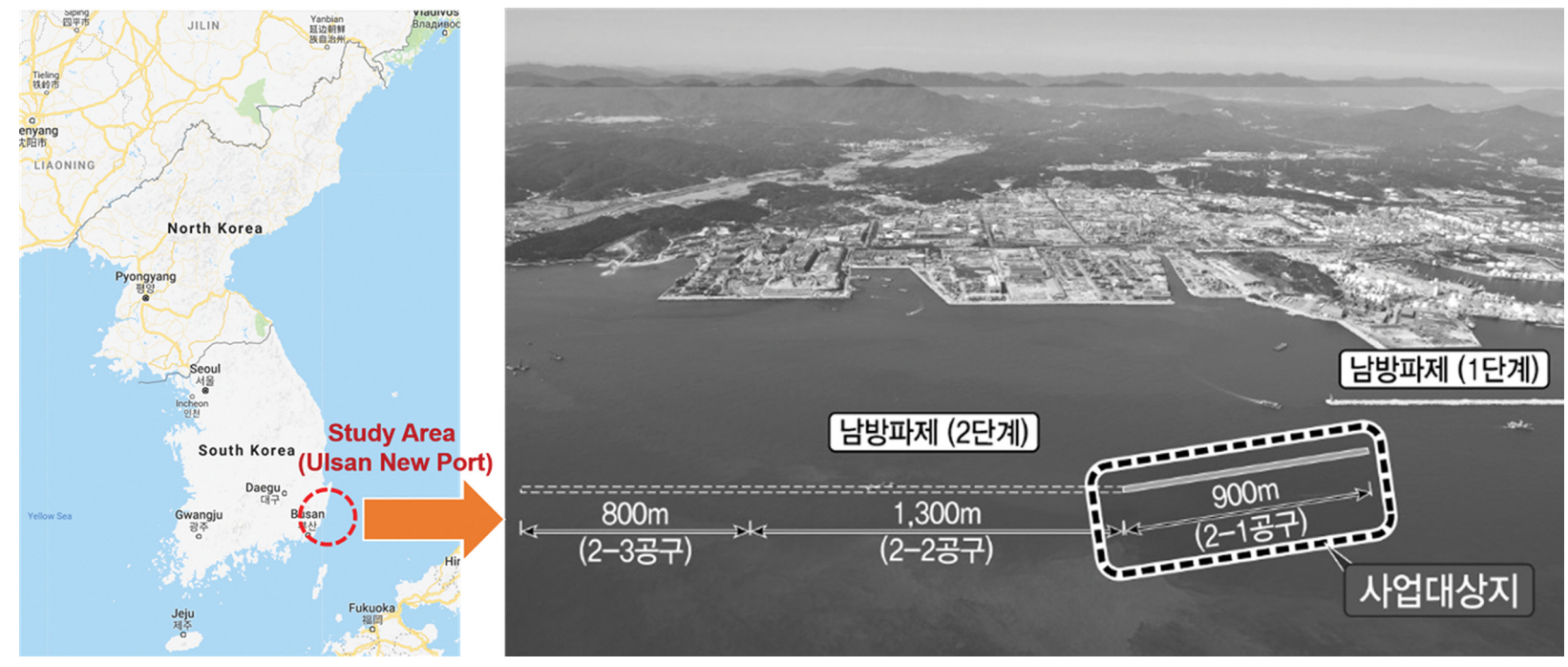

Fig. 1. Map (left) and aerial photograph (right) of the study area. 
Table 1. Working days of Ulsan new port by design report (Southern breakwater Section 2-1)

\begin{tabular}{ccc}
\hline \hline Items & $\begin{array}{c}\text { Working days by theory } \\
(\text { Ro, 1969) }\end{array}$ & $\begin{array}{c}\text { Working days by construction report } \\
\text { of Ulsan Northern breakwater }\end{array}$ \\
\hline Land & 19.4 days/month & 21.1 days/month \\
Sea & 18.5 days/month & 22.0 days/month \\
\hline
\end{tabular}

Table 2. Working days of Ulsan new port by construction report (Southern breakwater Section 2-1)

\begin{tabular}{|c|c|c|c|c|c|c|c|c|c|c|c|c|c|}
\hline \multirow{2}{*}{ Items } & \multicolumn{12}{|c|}{ Working days per month of construction report } & \multirow{2}{*}{ Ave. } \\
\hline & 1 & 2 & 3 & 4 & 5 & 6 & 7 & 8 & 9 & 10 & 11 & 12 & \\
\hline Sea & 10 & 14 & 18 & 17 & 25 & 24 & 22 & 25 & 15 & 17 & 8 & 18 & 17.8 \\
\hline Land & 26 & 14 & 25 & 25 & 23 & 23 & 25 & 10 & 16 & 22 & 19 & 31 & 21.5 \\
\hline
\end{tabular}

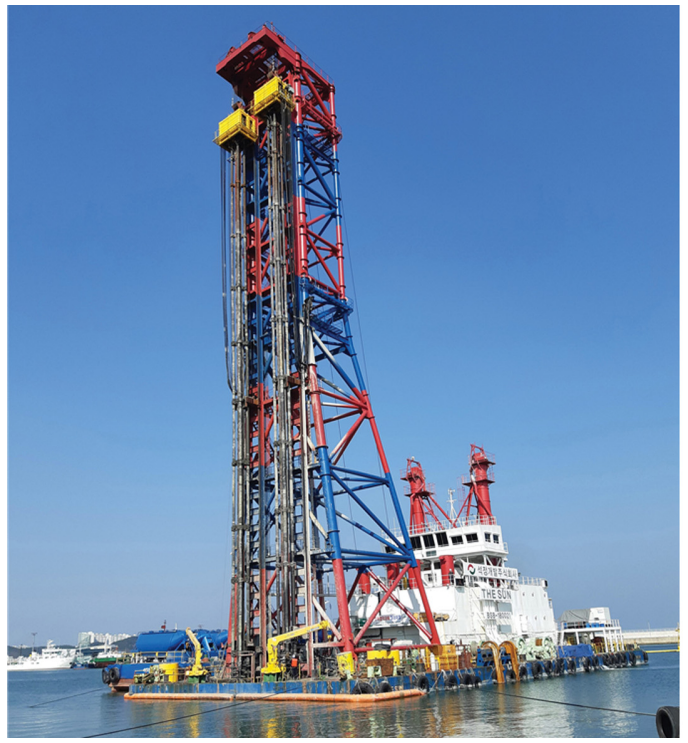

Fig. 2. Pictures of deep cement mixing work.

와 공사일지를 수집, 분석하였다. 보고서 검토결과 Table 1과 같이 Ro(1969)가 기상조건만을 고려하여 제안한 산정방법에 의한 작업일수와 인근 울산신항 북방파제 시공 실적 자료로 부터 산정한 작업일수를 비교한 후 인근 시공 실적 자료에 의 한 작업일수를 채택, 적용한 것으로 나타났다.

본 연구에서는 울산신항 남방파제 2-1공구 축조공사 시의 공사일지를 수집하여 분석하고 실시설계 당시에 적용한 작업 일수와 비교, 분석하였다. 공사일지 분석은 육상의 경우에 대 해서는 2015년 12월부터 2016년 11월까지 1년간의 케이슨 제작 공정을 기준으로 분석하였다. 해상의 경우에는 2015년 1월부터 12월 기간 동안 연약지반개량공법인 심층혼합처리 (Deep Cement Mixing, DCM) 공정에 대해서 분석하여 Table 2에 나타내었다. Fig. 2는 DCM 해상 작업사진이다.

울산신항 남방파제 2-1공구의 공사일지 분석결과 육상의 경 우에는 실시설계 당시 적용한 작업일수 21.1 일/월과 거의 유 사하게 21.5 일/월로 검토되었다. 하지만 해상의 경우에는 작 업일수가 17.8 일/월로 분석되어 실시설계 시 적용한 22 일/월 과는 4.2 일/월의 차이가 발생하는 것으로 나타났으며, 이를 연 간으로 환산하면 50.4 일의 큰 차이가 발생하는 것으로 분석

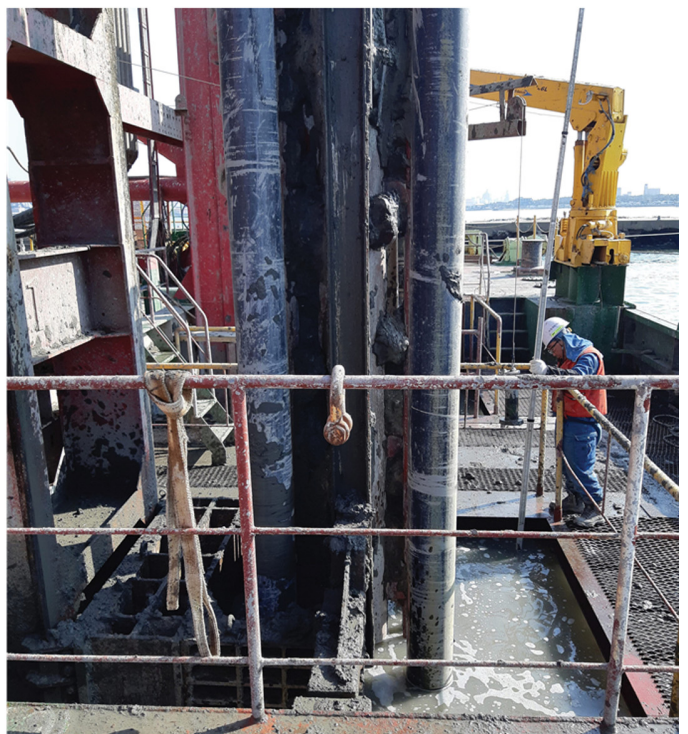

되었다. 이와 같은 차이가 발생한 주요 원인을 분석한 결과, 울산신항 북방파제의 경우에는 출현빈도가 높은 $\mathrm{NE}$ 계열 파 랑이 방어진항 등과 같은 돌출지형에 의해서 저감되어 북방 파제 전면해역까지 전파되지만, 울산신항 남방파제 2-1공구 는 내습파랑을 저감 시키는 지형 또는 구조물이 없어 $\mathrm{NE}$ 계 열 파랑이 직접 내습함으로 인해 파랑에 의한 비작업일수가 북방파제 공사 시보다 약 50 일 이상 많게 발생한 것으로 판 단된다.

이와 같이 해당 과업대상지가 기존 건설해역 인근에 위치 하더라도 파랑 조건이 상이한 기존 건설해역의 공사일지를 이 용하여 산정된 작업일수를 해당 과업대상지의 설계에 적용하 게 되면 시공단계에서 대기공정의 증가로 인한 비용 손실 및 공사기간을 맞추기 위해서 실시하는 무리한 작업진행에 따른 안전사고 발생을 유발할 수 있다.

\section{3. 장기 후측파랑 추산자료 생성}

“항만건설공사 설계실무요령(Ministry of Oceans and Fisheries, 2020)"에 의하면 항만건설공사 작업일수 산정에 있 


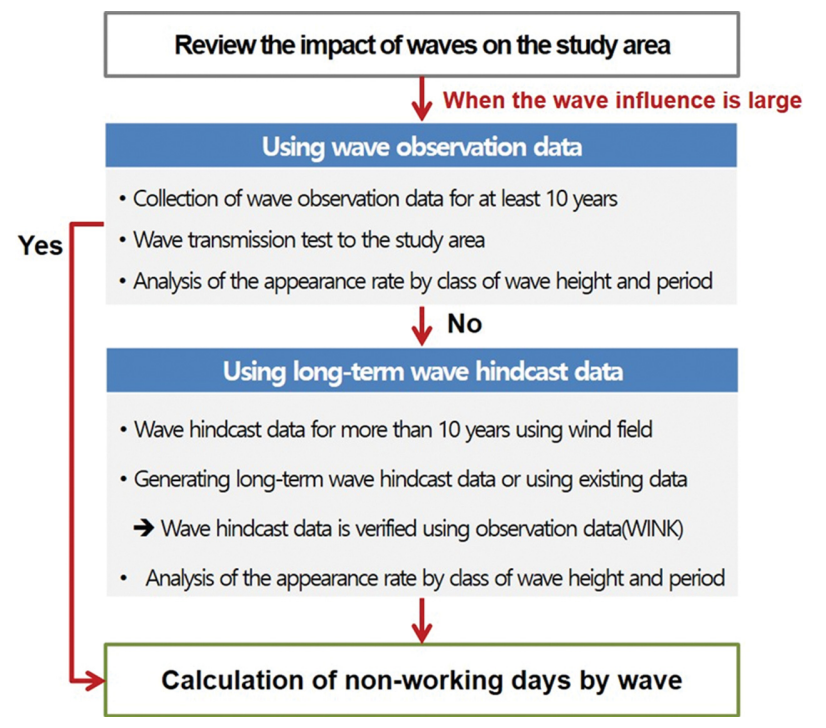

Fig. 3. Flow chart for calculation of non-working days by wave.

어 파랑을 고려한 해상작업일수 산정을 위해서는 과업대상지 에서의 10 년 이상의 장기파랑자료가 필요하다. 해상 작업일 수 산정을 위한 장기파랑자료는 대상지역의 파랑 관측자료나 수치모형실험을 수행하여 구하고 통계분석을 통해서 파고 및 주기의 계급별 출현율을 분석한 후 주공정의 작업한계파고를 적용하여 파랑에 의한 비작업일수를 산정하도록 Fig. 3과 같
이 제시하고 있다. 장기 파랑자료를 사용하는 방법은 과업대 상지 인근의 파랑 관측자료가 있는 경우에는 파랑 관측자료 를 수집하여 이용하고 파랑 관측자료를 이용하기 어려운 경 우에는 바람장을 이용하여 과업대상지 위치에서의 최근 10 년 이상 장기 후측파랑 추산자료를 생성하여 사용하여야 한다.

이에 본 연구에서는 연구대상지인 울산신항 남방파제 2-1 공구 인근에서의 파랑 관측자료를 조사하였다. 현재 연구대 상지인 울산신항 인근에서 수행되고 있는 장기 파랑 관측은 기상청 울산 부이 $(6 \mathrm{~m}$ 선박형 부이)와 해양수산부의 울산신 항(초음파식 파향.파고계, Signature ADCP 500) 위치에서 수 행되고 있는 것으로 조사되었으나, 관측 기간이 10 년 미만이 고 연구대상지와 이격되어 있어 파랑 관측자료를 이용한 해 상 작업일수 산정은 어려울 것으로 검토되었다. 따라서 본 연 구에서는 울산신항을 대상으로 JMA-MSM 바람장을 사용하 여 연구대상 위치에서의 장기 후측파랑 추산자료를 생성하고, 기상청 울산 부이와 해양수산부 울산신항 파랑 관측자료는 파 랑추산의 재현성 확인을 위한 검증자료로 활용하였다. 기상 청 울산부이와 해양수산부 울산신항 파랑 관측자료의 정보와 위치도는 각각 Table 3과 Fig. 4와 같다.

\section{1 후측파랑 추산실험 개요}

후측파랑 추산실험은 TU Delft(Delft Technical University)

Table 3. Basic information of the wave observation

\begin{tabular}{|c|c|c|c|c|}
\hline \multirow{2}{*}{ Station } & \multirow{2}{*}{ Observation periods } & \multicolumn{2}{|c|}{ Location } & \multirow{2}{*}{ Water depth } \\
\hline & & Latitude & Longitude & \\
\hline Ulsan (KMA) & 2015.12.22. Present & $35^{\circ} 20^{\prime} 43.08^{\prime \prime} \mathrm{N}$ & $129^{\circ} 5029.04^{\prime \prime} \mathrm{E}$ & D.L.(-) $144 \mathrm{~m}$ \\
\hline Ulsan new port (MOF) & 2018.11.01. Present & $35^{\circ} 23^{\prime} 30.01^{\prime \prime} \mathrm{N}$ & $129^{\circ} 22^{\prime} 52.20^{\prime \prime} \mathrm{E}$ & D.L.(-) $29 \mathrm{~m}$ \\
\hline
\end{tabular}

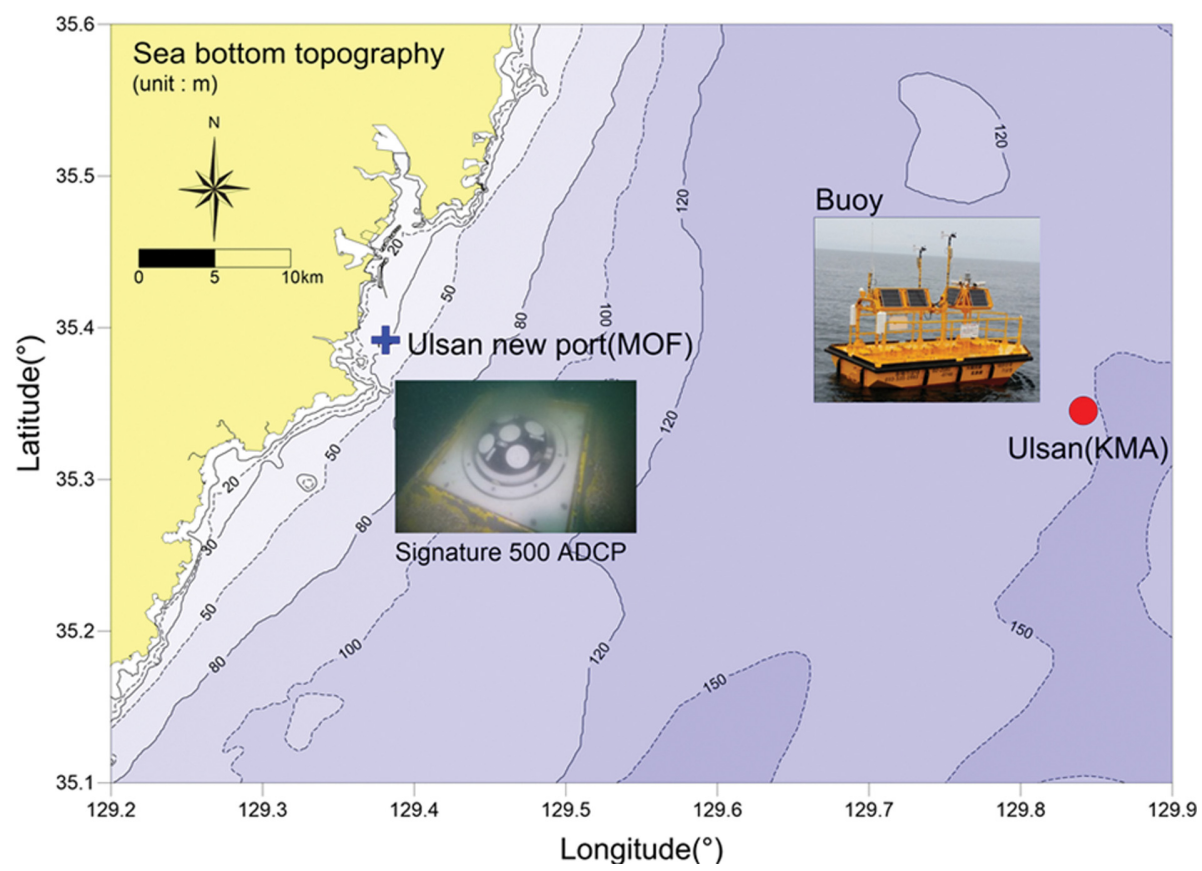

Fig. 4. Location of wave measurement stations. 


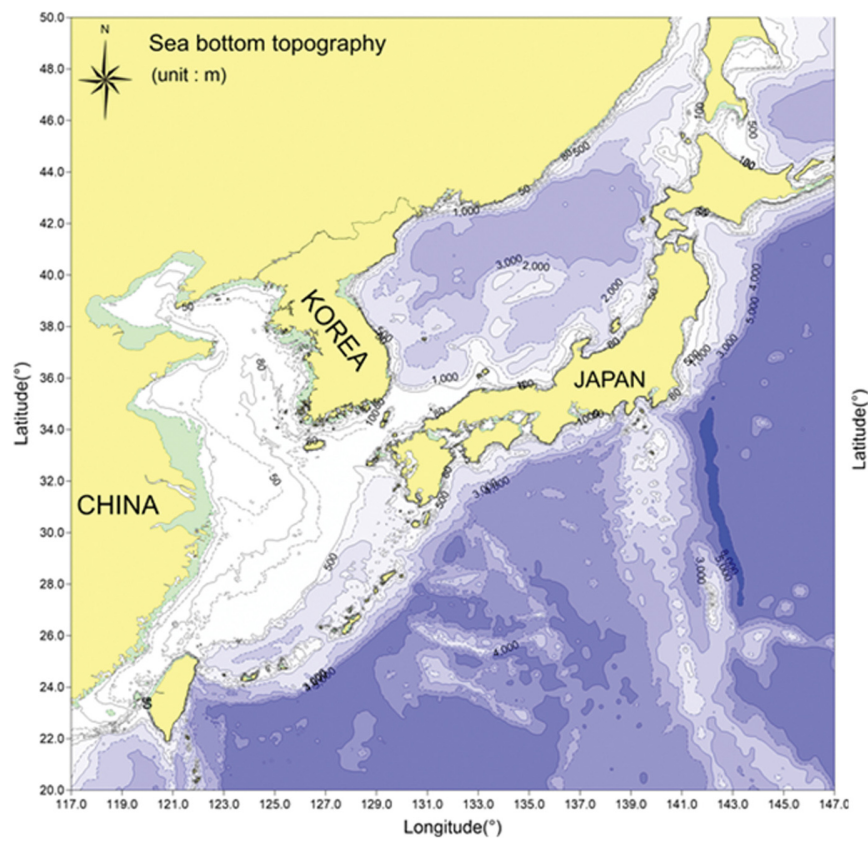

(a)

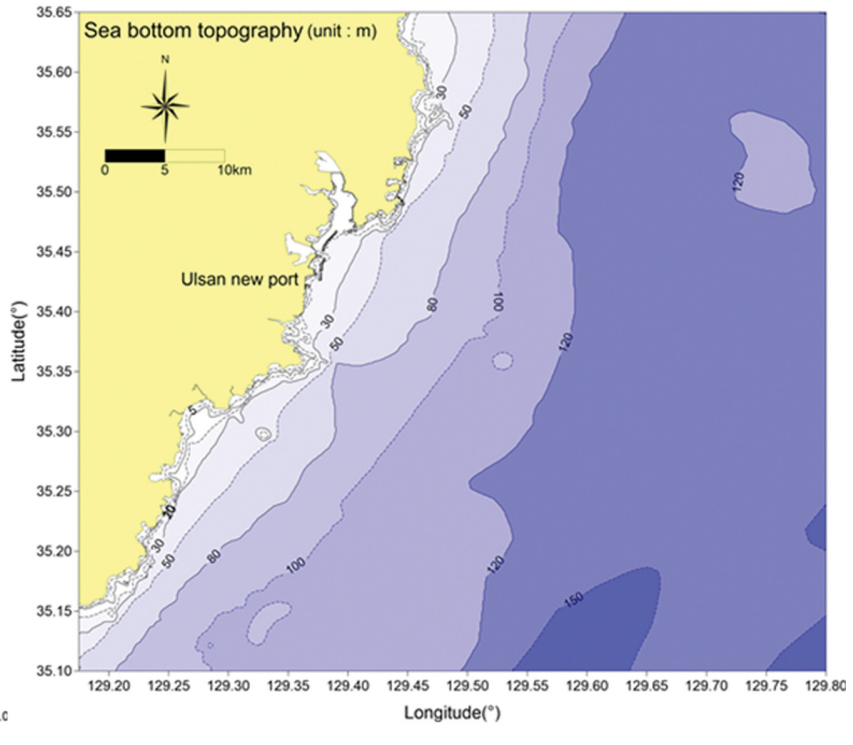

(b)

Fig. 5. Sea bottom topography for numerical modelling.

Table 4. Information of JMA-MSM, NOAA-NCEP, ECMWF wind field data

\begin{tabular}{ccclc}
\hline \hline Item & Period & Object range & Resolution & Remarks \\
\hline JMA-MSM & 2006.03. Present & East Asia & Latitude $0.05^{\circ}$, & 3 Hours interval \\
NOAA-NCEP & 2011.01. Present & $\left(22.4^{\circ} \sim 47.5^{\circ} \mathrm{N}, 120^{\circ} \sim 150^{\circ} \mathrm{E}\right)$ & $\begin{array}{l}\text { Longitude } 0.0625^{\circ} \\
\text { Latitude } 0.2045^{\circ},\end{array}$ & 1 Hour interval \\
Longitude $0.2045^{\circ}$ & Latitude $0.125^{\circ}$, & 6 Hours interval \\
ECMWF & 2012.02. Present & Global & Longitude $0.125^{\circ}$ & Global \\
\hline
\end{tabular}

에서 개발한 SWAN(Simulation WAves Nearshore) 모델을 사용하고 시계열 바람장을 입력하여 울산신항 해역의 파랑 추 산자료를 생성하였다. 실험영역은 Fig. 5와 같이 전해역(a)과 상세역(b)으로 구분하고 SWAN 모델의 Nesting 기법을 적용 하여 파랑추산의 정밀도를 높이고자 하였다. 전해역은 태풍 의 생성부터 발달까지 모의할 수 있도록 동아시아를 포함하 여 구성하고, 격자간격은 $1 / 20^{\circ}$ (약 $5 \mathrm{~km}$ 해상도)로 설정하였 다. 상세역은 울산신항을 중심으로 구성하고 격자간격은 1/ $1,000^{\circ}$ (약 $100 \mathrm{~m}$ 해상도)로 상세하게 설정하였다.

후측파랑 추산실험의 입력바람장은 공간해상도가 우수한 JMA-MSM 예보 바람장을 수집하여 사용하였다(Kim et al., 2020). 일본 기상청(JMA)에서는 2006년 3월 1일부터 현재까 지 $22.4^{\circ} \sim 47.5^{\circ} \mathrm{N}, 120^{\circ} \sim 150^{\circ} \mathrm{E}$ 의 범위에서 위도 $1 / 20^{\circ}$, 경도 $1 / 16^{\circ}$ 의 해상도로 매 3 시간 간격의 해상풍 예보 자료를 제공 하고 있다. JMA-MSM(일본기상청) 예보 바람장과 함께 파 랑추산 시 입력바람장으로 사용할 수 있는 NOAA-NCEP(미 국해양대기청), $\mathrm{ECMWF}$ (유럽중기예보센터) 바람장 정보를 Table 4에 나타내었다.

장기 후측파랑 추산자료는 2010년부터 2019년까지 10년간 에 대해서 JMA-MSM 바람장을 사용하여 1시간 간격의 유
의파고 $\left(H_{s}\right)$, 첨두주기 $\left(T_{p}\right)$ 및 대표파향 등의 시계열 파랑 자 료를 생성하였으며, 울산신항 인근의 기상청 울산부이, 해양 수산부의 울산신항 파랑 관측자료와의 비교, 검증을 통해서 재현성을 확보하였다.

파랑추산실험 시 불규칙파의 스펙트럼은 JONSWAP 스펙 트럼을 사용하였고, 방향은 $0 \sim 360^{\circ}$ 구간을 60 개로 분할하고, 주파수는 $0.04 \sim 1.0 \mathrm{~Hz}$ 구간을 40개로 분할하였다. 바람에 의 한 파랑의 발달은 $\mathrm{KOMEN}$ 파라메터를 적용하고, 바닥 마찰 효과와 쇄파에 의한 효과 등은 SWAN 모형의 Default 조건 을 기본으로 사용하였다.

\section{2 파랑 관측자료를 이용한 검증}

후측파랑 추산자료의 재현성을 검증하기 위해서 해양수산 부에서 구축한 전국파랑 관측자료 제공시스템(WINK)에서 제 공하는 품질관리된 기상청의 울산부이 파랑 관측자료를 수집 하였으며, 근해의 파랑 추산자료 검증을 위해서 울산신항 남 측 수심 $29 \mathrm{~m}$ 해저에 해양수산부에서 설치·운영 중인 착저 식 파향.파고계 관측자료를 수집하였다. 울산신항 동측 약 $40 \mathrm{~km}$ 에 위치하는 기상청 울산부이 파랑 관측자료는 전해역 파랑추산 결과를 검증하는데 이용하였으며, 연구대상지인 울 

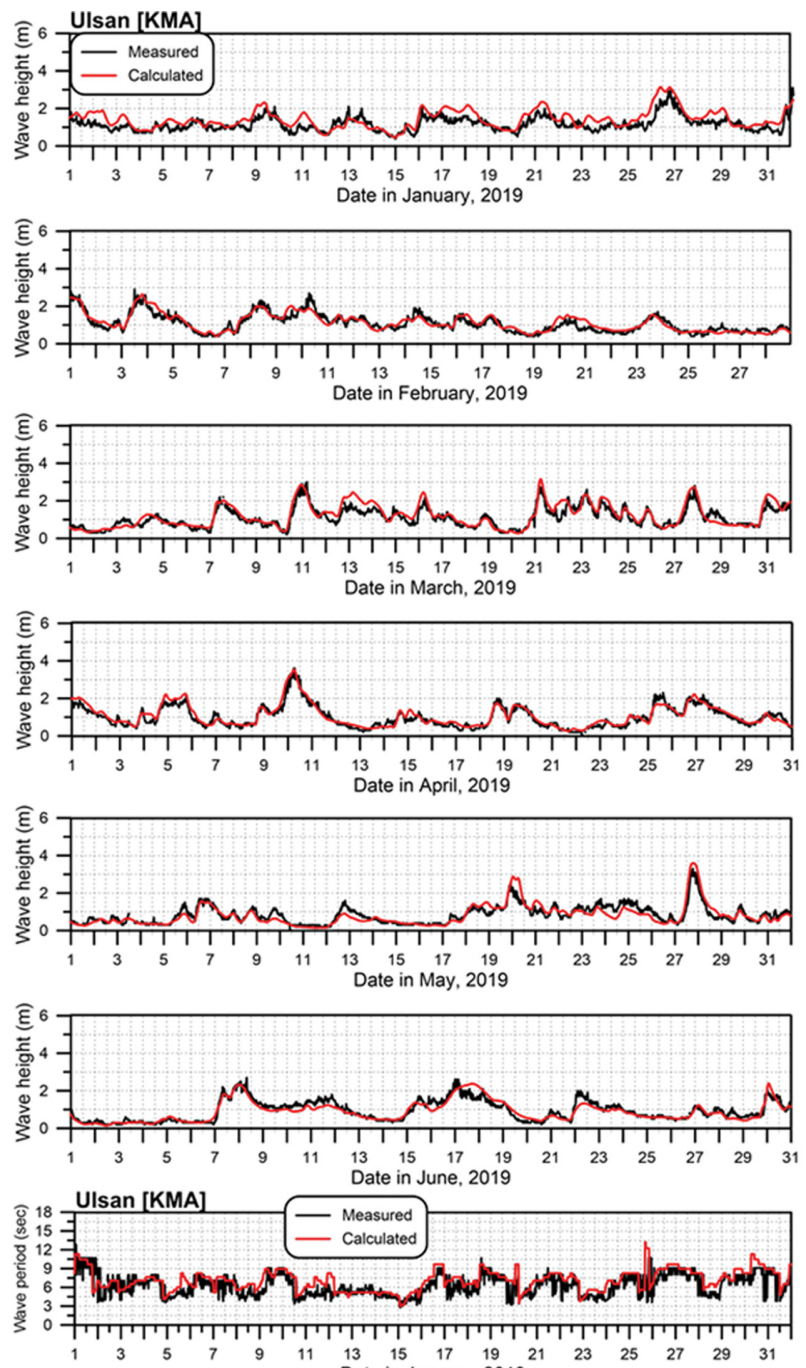

$\begin{array}{llllllllll}13 & 15 & 17 & 19 & 21 & 23 & 25 & 27 & 29 & 31\end{array}$

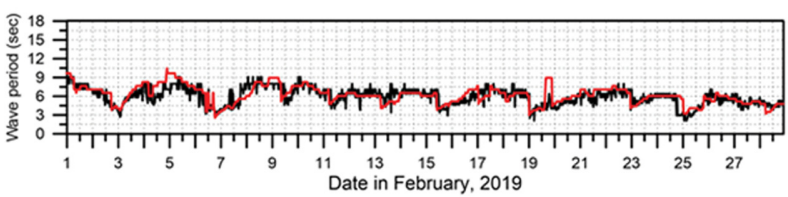
Date in March, 2019

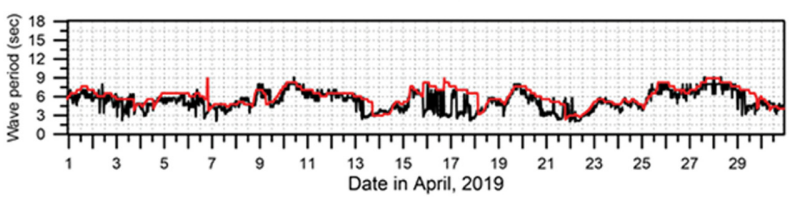

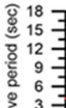

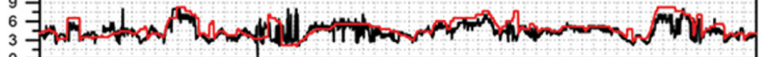

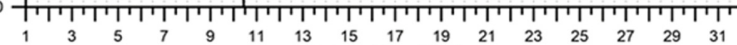

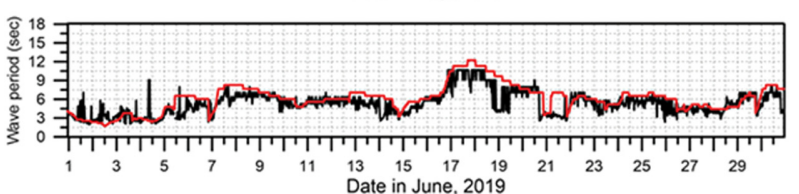

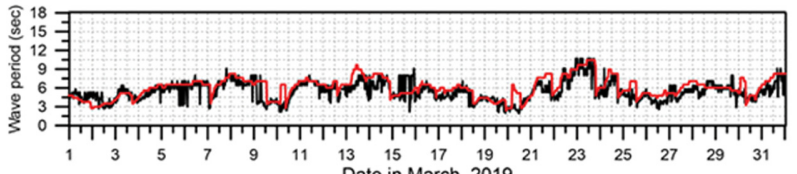
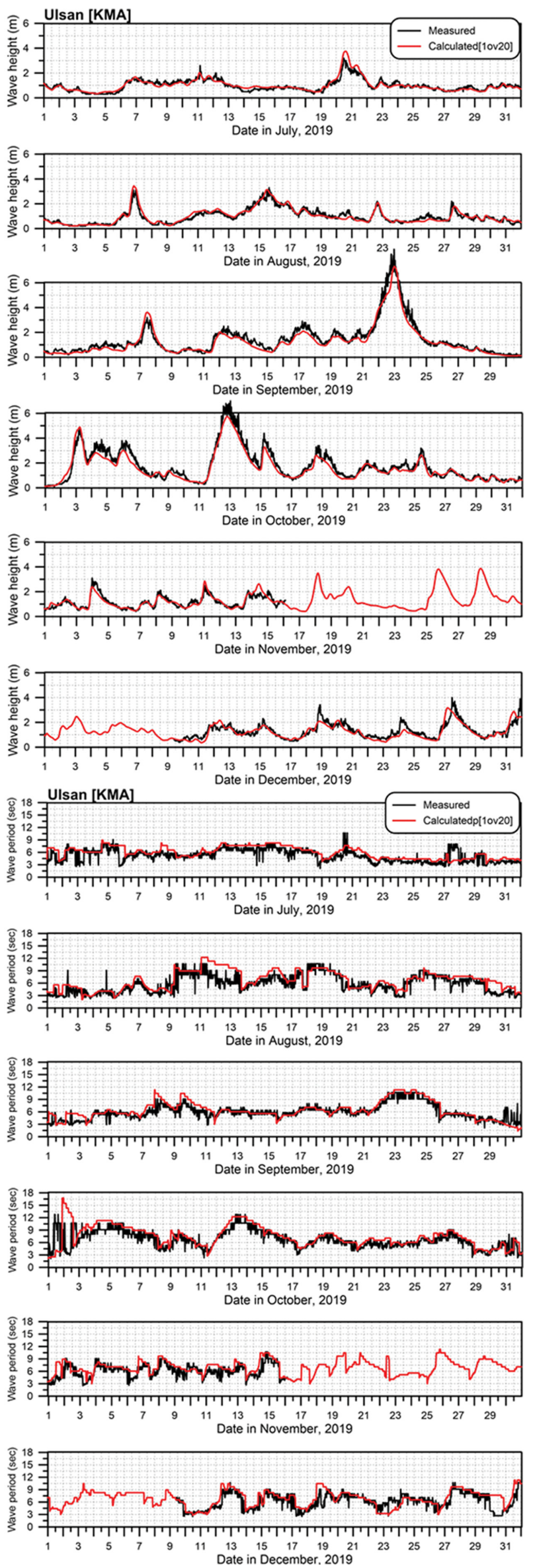

Fig. 6. Comparison of the significant wave height and period for measured and hindcasted (KMA ulsan buoy, 2019). 

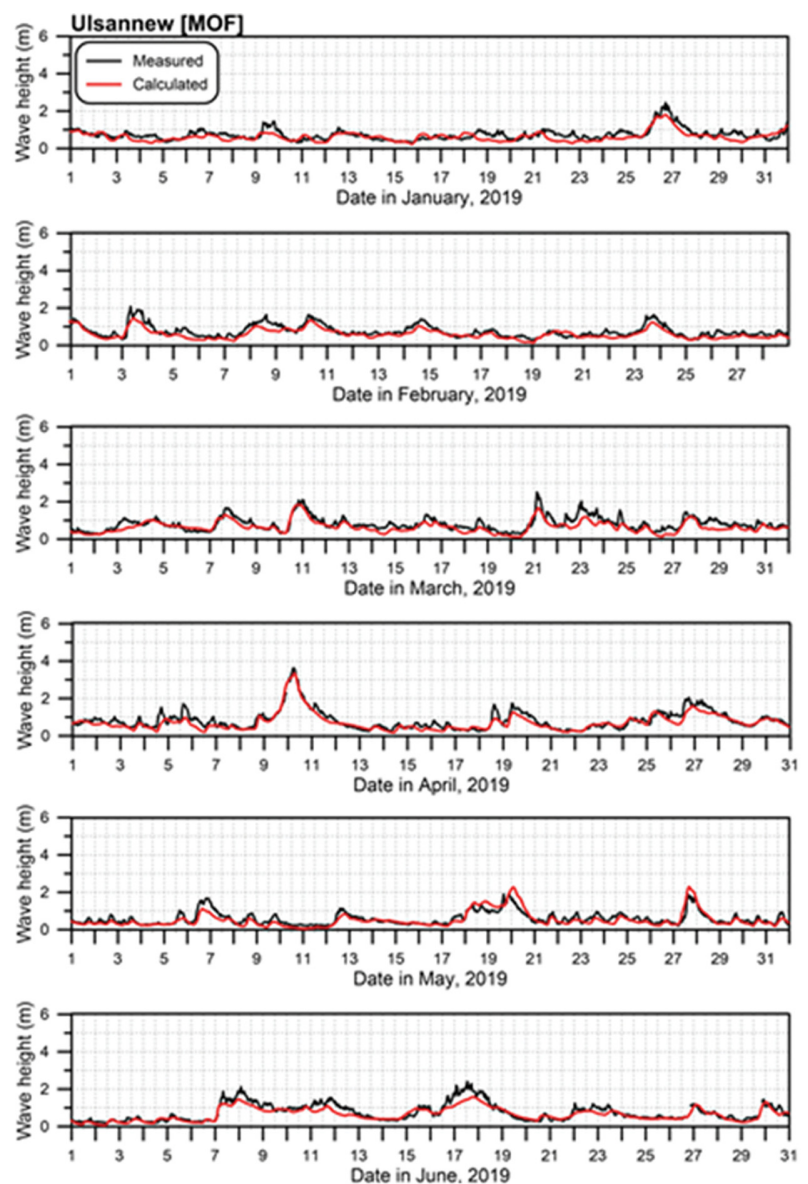

— Measured
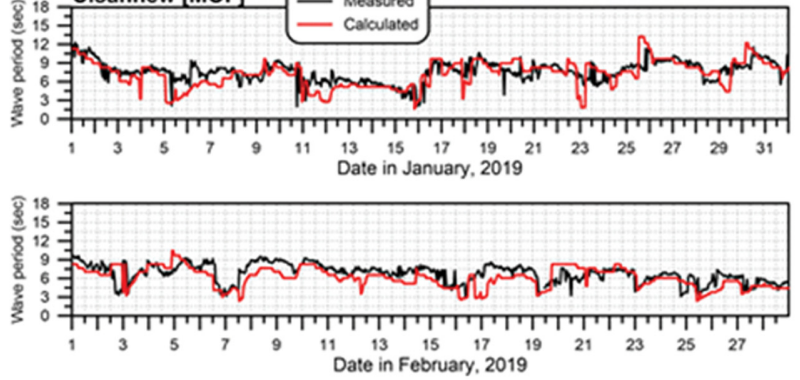
Date in March, 2019
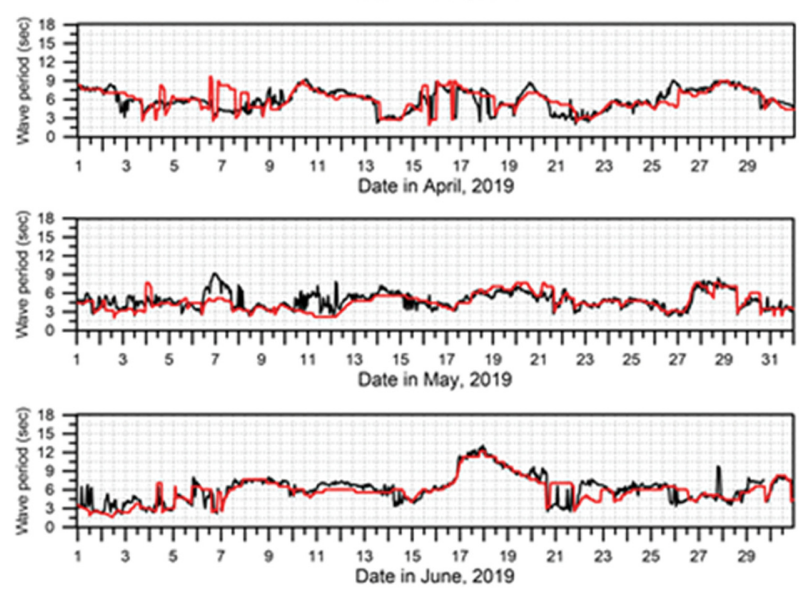

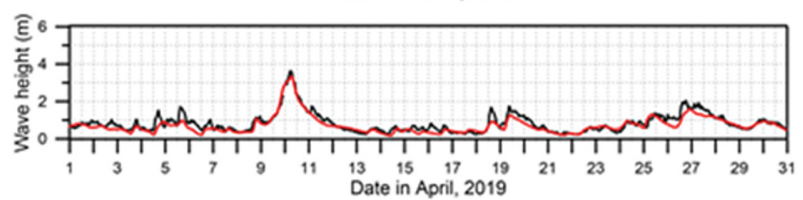

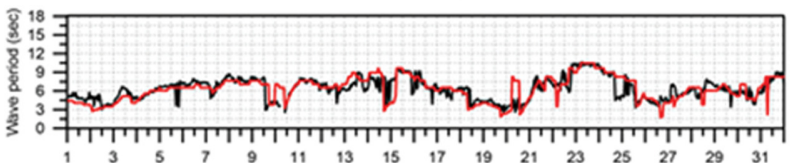
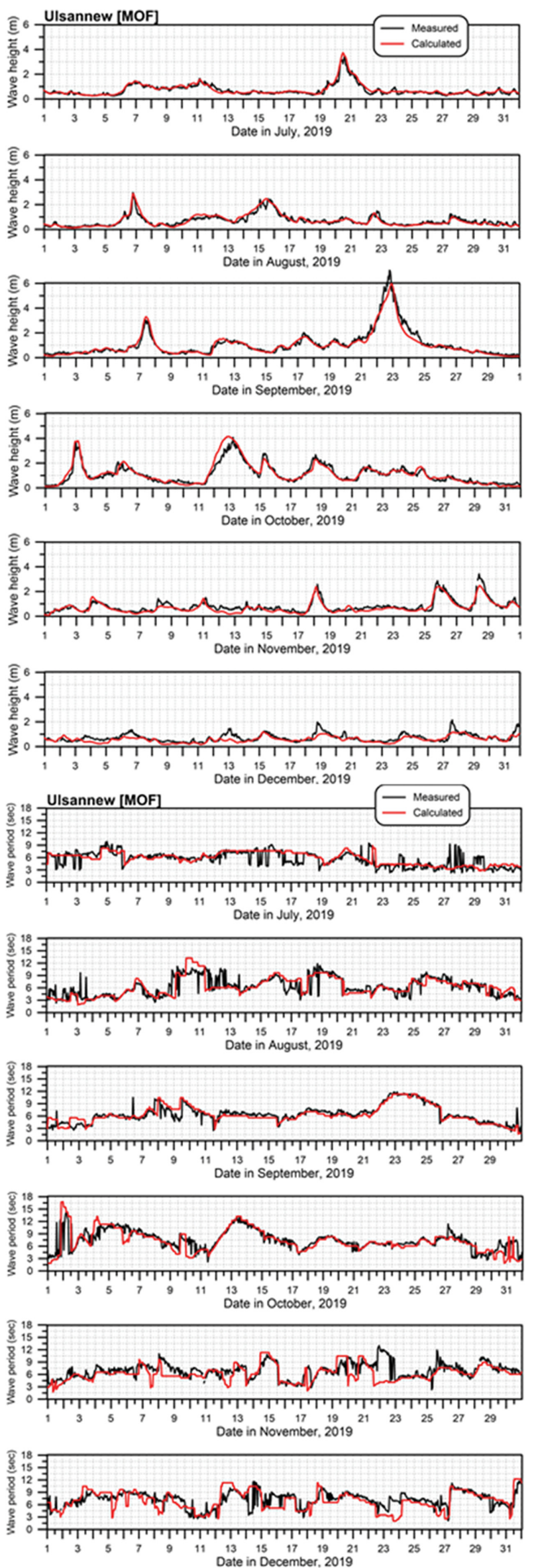

Fig. 7. Comparison of the significant wave height and period for measured and hindcasted (MOF ulsan new port, 2019). 

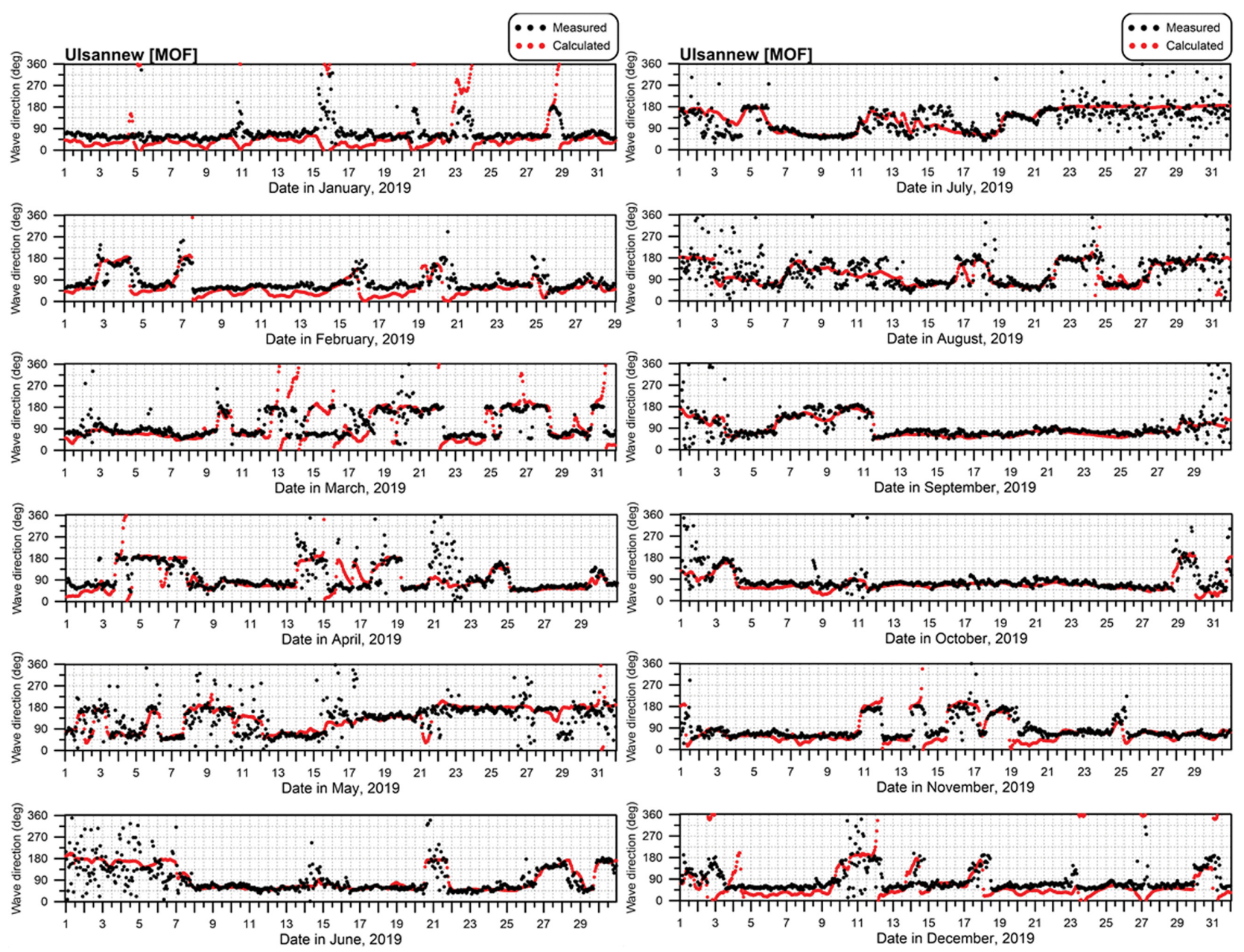

Fig. 8. Comparison of the peak direction for measured and hindcasted (MOF ulsan new port, 2019).

산신항 남방파제 2-1공구 남측 약 $3 \mathrm{~km}$ 에 위치하는 해양수 산부 울산신항 파랑 관측자료는 상세역 파랑추산 결과의 재 현성을 검증하기 위해서 사용하였다.

전국파랑 관측자료 제공시스템에서 국립해양조사원과 해양 수산부의 파랑 관측자료는 유의파고, 주기 및 파향을 모두 제 공하고 있지만 기상청 파랑 관측자료는 유의파고와 주기만 제 공하고 정확도 검토가 진행 중인 파향은 제공하고 있지 않다. 이에 본 연구에서는 기상청 울산 부이 위치에서의 검증은 유 의파고와 주기에 대해서 수행하고 해양수산부 울산신항 파랑 관측 위치에서는 유의파고, 주기 및 파향에 대해서 계산치와 관측치의 검증을 수행하였다. 후측파랑 추산자료의 검증은 2019년 1월부터 12월까지 1년간에 대해서 수행하였으며, 먼 저 관측치와 계산치의 시간 동기화된 시계열 유의파고, 첨두 주기 및 파향 자료의 재현성을 검토하였으며, 이를 도시한 것 이 Fig. 6 Fig. 8 이다.

기상청 울산 부이에서의 관측치와 전해역 후측파랑 추산자 료의 시계열 자료 비교·분석 결과, 유의파고와; 주기의 시계 열 변화 경향이 유사하게 나타났다. 상세역 후측파랑 추산자 료 검증을 위한 해양수산부 울산신항 파랑관측 위치에서의 유 의파고, 첨두주기 및 파향 시계열 결과도 관측치와 계산치의
경향이 유사하게 나타나 전반적으로 수치모형실험의 재현성 이 양호한 것으로 판단된다. 특히, 2019년 하계에 내습하여 항만 및 연안역에 태풍 피해를 발생시킨 태풍 TAPAH(1917) 내습 시의 고파랑도 관측치와 유사한 경향을 보이고 있어 후 측파랑추산자료의 재현성이 우수한 것으로 검토되었다.

또한, 후측파랑 추산자료의 정량적인 검증을 위해서 관측 치와 계산치의 유의파고를 사용하여 상관성을 분석한 결과 울 산 부이 위치에서 결정계수 $\left(R^{2}\right)$ 는 0.96 , Slope은 0.97 로 나타 났으며, 울산신항 위치에서의 결정계수 $\left(R^{2}\right)$ 는 0.95 , Slope은 0.91 로 산정되어 후측파랑 추산자료가 관측치를 잘 재현하고 있는 것으로 검토되었다(Fig. 9 참조).

\section{3 장기 후측파랑 추산자료 생성}

울산신항 남방파제 2-1공구 축조공사 시 공사일지와의 비 교분석을 수행하고 “항만건설공사 설계실무요령"에서 제시한 파랑에 의한 비작업일수 산정방법의 적정성을 검토하기 위해 서 Fig. 10에 도시된 연구대상 위치에서 2010년부터 2019년 까지 10 년 동안의 유의파고 $\left(H_{s}\right)$, 주기 $\left(T_{p}\right)$ 및 파향 시계열 자 료를 생성하였다.

연구대상지인 울산신항 해역의 파랑 특성을 분석하기 위해 

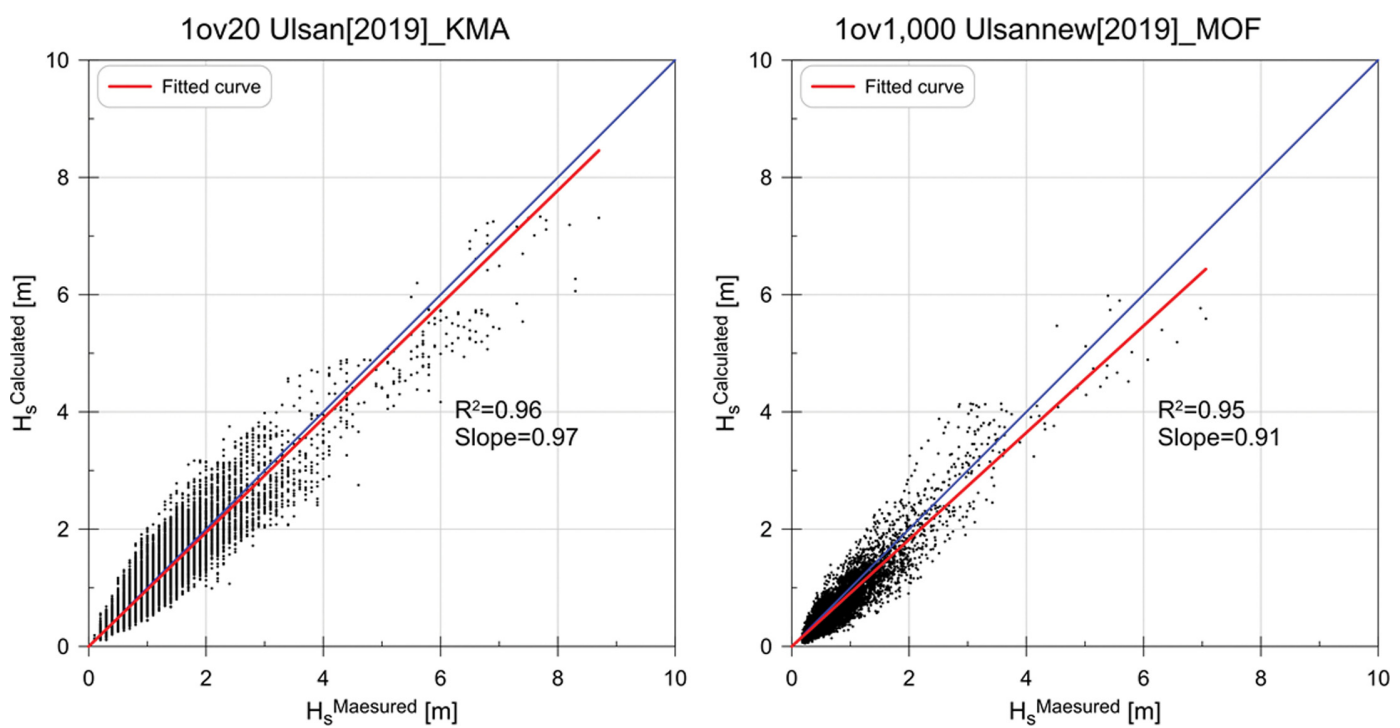

Fig. 9. Correlation analysis result for wave data measured and hindcasted.

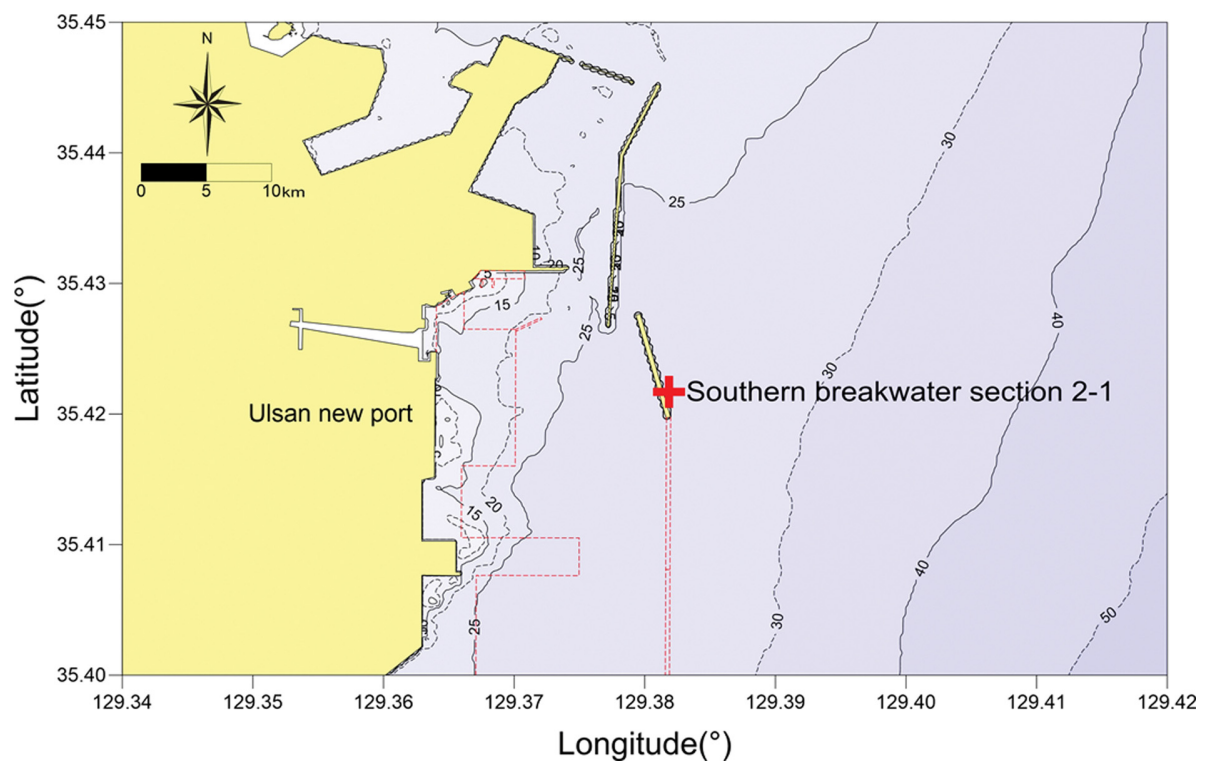

Fig. 10. Location of long-term wave hindcasting data.

Table 5. Appearance rate of wave height and period (2010 2019)

\begin{tabular}{|c|c|c|c|c|c|c|c|c|}
\hline$T_{p}(\mathrm{~s})$ & $\sim 0.8$ & $0.8 \sim 1.0$ & $1.0 \sim 1.5$ & $1.5 \sim 2.0$ & $2.0 \sim 3.0$ & $3.0 \sim$ & Sum & Prop (\%) \\
\hline$\sim 5.0$ & 24,588 & 1,379 & 537 & 7 & - & - & 26,511 & 30.2 \\
\hline $5 \sim 8$ & 28,789 & 6,680 & 6,356 & 1,946 & 689 & 29 & 44,489 & 50.8 \\
\hline $8 \sim 10$ & 7,722 & 1,368 & 1,359 & 470 & 547 & 199 & 11,665 & 13.3 \\
\hline $10 \sim 12$ & 1,965 & 638 & 619 & 165 & 81 & 74 & 3,542 & 4.0 \\
\hline $12 \sim$ & 579 & 340 & 390 & 53 & 49 & 30 & 1,441 & 1.6 \\
\hline Sum & 63,643 & 10,405 & 9,261 & 2,641 & 1,366 & 332 & 87,648 & 100.0 \\
\hline Prop (\%) & 72.6 & 11.9 & 10.6 & 3.0 & 1.6 & 0.4 & 100.0 & - \\
\hline
\end{tabular}

서 파랑장미도를 작도하여 Fig. 11에 도시하였다. 파향별 출 현율을 검토한 결과, 전년에 걸쳐 $\mathrm{NE}$ 와 $\mathrm{ENE}$ 파향의 빈도가 가장 탁월하게 내습하는 것으로 나타났으며, 이와 같은 경향 은 춘계, 하계, 추계, 동계에도 거의 유사하게 나타났다. 춘
계와 하계의 경우에는 $\mathrm{ENE}$ 파향이 가장 많이 내습하지만 $\mathrm{S}$ 파향도 많이 내습하는 것으로 나타났다.

Table 5에 10년간의 장기 후측파랑 추산자료를 파고 및 주 기 계급별 출현율로 나타내었으며, 연구대상지의 경우에 $1.5 \mathrm{~m}$ 

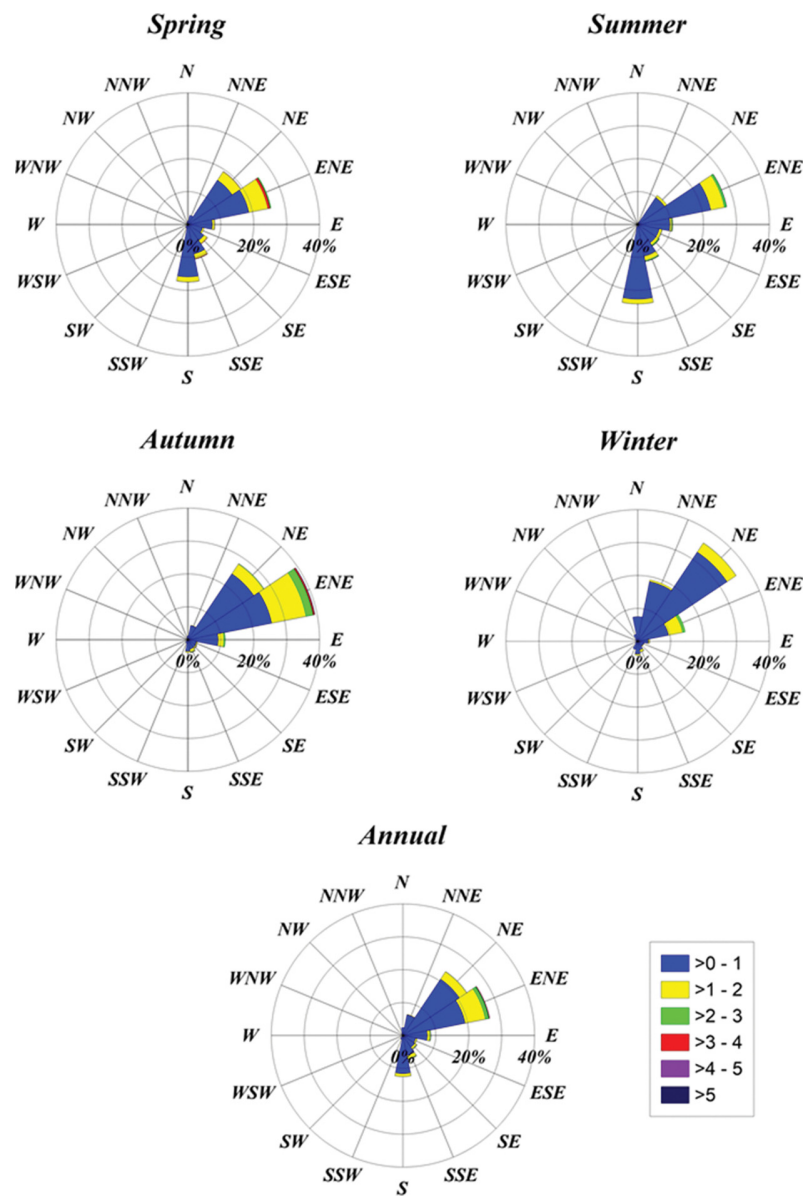

Fig. 11. Wave rose of long-term wave hindcasting data (2010 2019).

이상의 비교적 높은 유의파고가 연간 $5 \%$ 이상 내습하는 것 으로 나타났다. 주기의 경우에는 지반개량공의 작업한계에 영 향을 미치는 8 초 이상의 주기가 연간 $18.9 \%$ 이상 출현하는 것으로 분석되었다.

\section{4. 파랑에 의한 비작업일수 산정방법의 적정성 검토}

\section{1 공사일지 분석}

연구대상지인 울산신항을 대상으로 파랑에 의한 비작업일 수를 분석하기 위해서 울산신항 남방파제 2-1공구 축조공사 시의 공사일지를 수집하였다. 공사일지 분석은 파랑의 영향 을 받는 해상공사 중 1년 이상의 연속성을 가지고 2015년 1 월부터 2015년 12월까지 공사를 수행한 방파제 축조공사의 주공정인 지반개량공 $(\mathrm{DCM})$ 을 대상으로 수행하였다. "항만건
설공사 설계실무요령(MOF, 2020)"에서는 지반개량공(DCM) 의 작업제한조건을 Table 6 과 같이 유의파고 $\left(H_{s}\right) 1.5 \mathrm{~m}$ 이상 또는 유의파고 $\left(H_{s}\right)$ 가 $1.0 \sim 1.5 \mathrm{~m}$ 이고 주기 $\left(T_{p}\right)$ 8.0초 이상으로 제시하고 있다.

공사일지 분석결과 비작업일 발생의 원인이 대부분 기상악 화로 작성되어 있어 공사일지를 통해서 직접적으로 파랑에 의 한 원인으로 인해 발생한 비작업일을 계상하는 것은 어려움 이 있는 것으로 검토되었다. 이에 본 연구에서는 관측자료와 의 검증을 통해 재현성을 확보한 연구대상 위치에서 추산한 2015년의 후측파랑 자료와 공사일지를 상호 비교하여 파랑에 의한 비작업일수를 계상하였다. 즉, 공사일지의 비작업일과 방 파제 축조공사 위치에서 추산한 후측파랑 시계열 자료 중 일 작업 시간인 오전 8시부터 17 시까지 유의파고 $\left(H_{s}\right) 1.5 \mathrm{~m}$ 이 상 또는 유의파고 $\left(H_{s}\right)$ 가 1.0 1.5 m이고 주기 $\left(T_{p}\right)$ 8.0초 이상 인 파랑이 1 회 이상 출현한 경우가 중복되면 파랑에 의한 비 작업일수로 계상하였다. 공사일지 분석결과 파랑에 의한 비 작업일수는 43 일로 분석되었다.

2015년의 후측파랑 시계열 자료만을 이용하여 지반개량공 의 작업한계 파랑조건(유의파고 $\left(H_{s}\right) 1.5 \mathrm{~m}$ 이상 또는 유의파 고 $\left(H_{s}\right)$ 가 $1.0 \sim 1.5 \mathrm{~m}$ 이고 주기 $\left(T_{p}\right)$ 8.0초 이상 $)$ 을 기준으로 Fig. 12와 같이 본 연구에서 제안하는 일별 작업제한 파랑조 건에 의해 산정한 비작업일수는 48 일로 나타났다. 이를 울산 신항 남방파제 2-1공구 축조공사의 공사일지와 비교한 결과 43 일은 비작업일수로 나타났지만 5 일은 작업을 진행한 것으 로 검토되었다. 해상작업을 진행한 5 일에 대해서 공사일지를 상세히 분석한 결과, 2 일은 작업 도중 피항하였고, 1 일은 작 업대기 상태, 1 일은 오전은 작업을 하고, 오후는 작업대기를 수행한 것으로 나타나 작업한계 파랑이 내습한 시기에 온전 히 공사를 수행한 날은 1 일 밖에 없는 것으로 분석되었다. 따 라서 후측파랑 추산자료를 이용한 공사일지 분석의 정확도가 상당히 높은 것을 확인할 수 있었다. 또한, “항만건설공사 설 계실무요령"에서 제시하고 있는 지반개량공의 작업한계 파랑 조건이 적정하다는 것을 증명하는 결과로 판단된다.

한편, “항만건설공사 설계실무요령(MOF, 2020)"에서 제시 하고 있는 파랑출현율에 의한 비작업일수를 산정한 결과는 35 일로 나타나 본 연구에서 제안한 일별 작업한계 파랑조건에 의한 비작업일수 보다 약 13 일 정도 작게 산정되는 것으로 나타났다.

파랑출현율에 의한 지반개량공의 비작업일수는 Table 7에 제시된 유의파고 $1.5 \mathrm{~m}$ 이상 출현율(주기 전체)과 유의파고 $1.0 \sim 1.5 \mathrm{~m}$ 의 출현율(주기 8 초 이상)을 다음과 같이 합산한 일 수이다.

Table 6. Work restriction conditions by wave

\begin{tabular}{cl}
\hline \hline Item & \multicolumn{1}{c}{ Work restriction conditions } \\
\hline Wave & Significant wave height of $1.5 \mathrm{~m}$ or more \\
$(\mathrm{DCM})$ & Significant wave height of $1.0 \sim 1.5 \mathrm{~m}$ and period $8.0 \mathrm{sec}$ or more \\
\hline
\end{tabular}




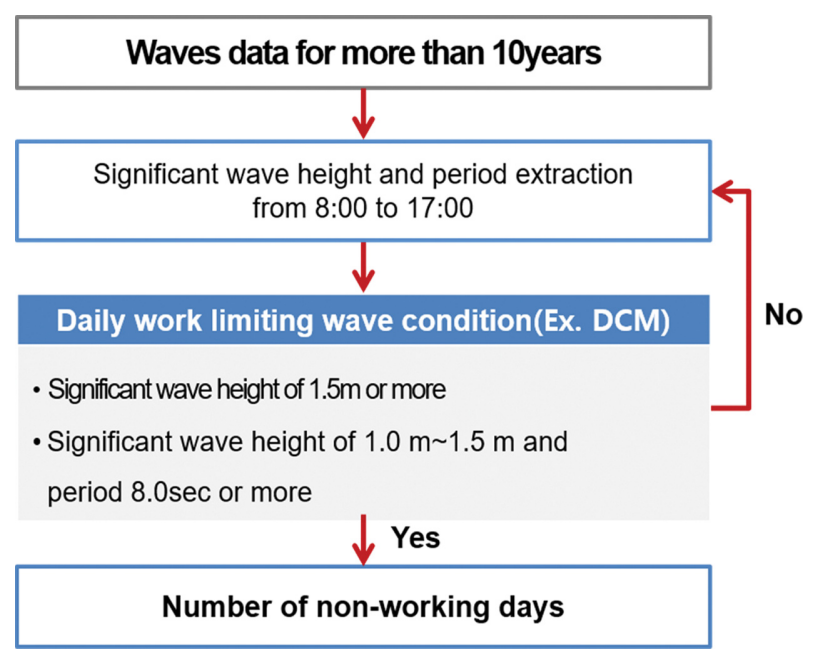

Fig. 12. Calculation method of non-working days by daily work limiting wave condition.

파랑에 의한 비작업일수 $=$ 파고 $1.5 \mathrm{~m}$ 이상 출현율(주기 전체) + 파고 $1.0 \sim 1.5 \mathrm{~m}$ 의 출현율(주기 8초 이상) $=(5.5 \%+4.2 \%) \times 365=35$ 일

이와 같은 분석결과로부터 파랑에 의한 해상작업일수 산정 에 있어 파랑출현율을 이용하는 방법보다 본 연구에서 제안 하는 일별 작업한계 파랑조건을 적용하여 산정하는 방법이 적 정한 것으로 사료된다.

울산신항 남방파제 2-1공구의 공사일지분석, 파랑출현율에 의한 방법, 일별 작업한계 파랑조건에 의한 방법을 적용하여 산정한 비작업일수를 Table 8에 나타내었다.

\section{2 파랑에 의한 비작업일수 산정(안) 제안}

울산신항 남방파제 2-1공구 축조공사의 2015년 1월부터 12 월까지 1 년간의 지반개량공 $(\mathrm{DCM})$ 공정의 공사일지와 후측 파랑 추산자료를 이용하여 도출한 일별 작업제한 파랑조건에 의한 비작업일수 산정방법을 Fig. 12에 나타내었다.
본 연구에서 제안하는 일별 작업제한 파랑조건에 의한 비 작업일수를 산정하기 위해서는 "항만건설공사 설계실무요령 (MOF, 2020)"에서 제안하고 있는 것과 같이 우선 과업 대 상위치에서의 최근 10 년 간의 후측파랑 추산자료를 생성해 야한다. 파랑에 의한 비작업일수 산정의 정확도를 높이기 위 해서는 파랑 관측자료와의 검증을 통한 후측파랑 추산자료 의 재현성 확보가 중요하며, 과업 대상위치의 수심 및 지형 을 고려한 파랑자료 생성을 위해서 최소 $200 \mathrm{~m}$ 이하 격자 해상도에서 파랑추산을 수행하는 것이 적절할 것으로 판단 된다.

정확도가 검증된 10 년 간의 후측파랑 추산자료가 확보되 면, 파랑 시계열 자료 중에서 일작업시간인 8시부터 17 시까 지의 유의파고와 첨두주기를 추출한 후 해상 건설공정 중 주 요공정별 작업한계 파랑조건을 각각 적용하여 파랑에 의한 비 작업일수를 산정한다. 단, 작업한계 파랑조건 이상의 파랑이 일작업시간내에 1 회 이상 출현 시 비작업일수로 계상한다.

본 연구에서 도출한 일별 작업제한 파랑조건에 의한 비작 업일수 산정방법을 실해역에 적용해 보았다. 실해역 적용은 연구대상지인 울산신항 남방파제 2-1공구에 대해서 수행하였 다. 먼저 2010년 1월 1일부터 2019년 12월 31일까지 10년 간의 고해상도(약 $100 \mathrm{~m}$ 격자해상도) 장기 후측파랑 추산자 료를 산출하였다. 그리고 일작업 시간 8시 17시를 기준으로 지반개량공 $(\mathrm{DCM})$ 의 작업한계 파랑조건을 적용하여 비작업 일수를 산정한 결과 Fig. 13과 같이 39일로 계산되었다. 이 는 2015년 1년간의 후측파랑 추산자료를 이용하여 동일한 방 법으로 비작업일수를 산정하였을 때의 48일 보다 9일 작게 산정된 것이며, 이와 같은 원인은 2015년에 고파랑의 출현빈 도가 최근 10 년 평균 보다 높게 나타나 발생한 현상으로 사 료된다.

한편, “항만건설공사 설계실무요령”에서 제시한 파랑출현 율에 의한 방법을 적용한 경우의 비작업일수는 28 일로 산정 되어 본 연구에서 제안하는 일별 작업한계 파랑조건을 적용 한 방법에 비해서 11 일 정도 작게 산정되었다.

Table 7. Appearance rate of wave height and period (2015. 1. 1 12. 31)

\begin{tabular}{|c|c|c|c|c|c|c|c|c|}
\hline$T_{p}(\mathrm{~s})$ & $\sim 0.8$ & $0.8 \sim 1.0$ & $1.0 \sim 1.5$ & $1.5 \sim 2.0$ & $2.0 \sim 3.0$ & $3.0 \sim$ & Sum & Prop (\%) \\
\hline$\sim 5.0$ & 2,690 & 130 & 46 & - & - & - & 2,866 & 32.7 \\
\hline $5 \sim 8$ & 2,446 & 375 & 573 & 218 & 67 & - & 3,679 & 42.0 \\
\hline $8 \sim 10$ & 925 & 178 & 225 & 50 & 89 & 5 & 1,472 & 16.8 \\
\hline $10 \sim 12$ & 269 & 111 & 72 & 17 & 15 & 12 & 496 & 5.7 \\
\hline $12 \sim$ & 112 & 63 & 72 & - & - & - & 247 & 2.8 \\
\hline Sum & 6,442 & 857 & 988 & 285 & 171 & 17 & 8,760 & 100.0 \\
\hline Prop (\%) & 73.5 & 9.8 & 11.3 & 3.3 & 2.0 & 0.2 & 100.0 & - \\
\hline
\end{tabular}

Table 8. Calulation result of non-working days

\begin{tabular}{cccc}
\hline \hline Item & Construction report & Wave appearance rate & $\begin{array}{c}\text { Daily work limiting } \\
\text { wave condition }\end{array}$ \\
\hline Non-working day & 43 days & 35 days & 48 days \\
\hline
\end{tabular}




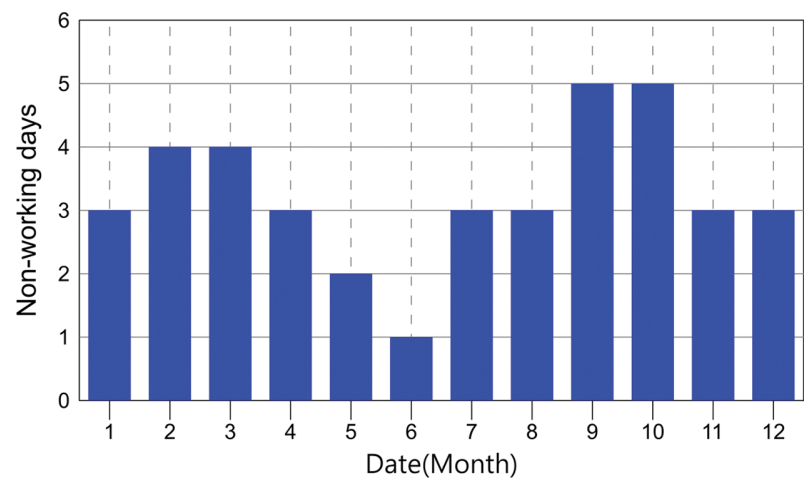

Fig. 13. Non-working days by daily work limiting wave condition.

\section{4. 결 론}

2020년 해양수산부에서 발간한 "항만건설공사 설계실무요 령”에서 제안하고 있는 파랑에 의한 항만공사 비작업일수 산 정방법의 적정성을 검토하고 개선방법을 제안하기 위해서 울 산신항 남방파제 2-1공구 축조공사 시의 공사일지를 수집하 고 연구대상지에서의 최근 10 년간 상세 후측파랑 추산자료를 생성하였다.

후측파랑 추산실험은 공간해상도(약 $5 \mathrm{~km}$ 해상도)가 우수 한 JMA-MSM 바람장을 이용하고 SWAN 수치모델의 Nesting 기법을 적용하여 전해역(약 $5 \mathrm{~km}$ 해상도)와 상세역(약 $100 \mathrm{~m}$ 해상도)실험을 연계하여 수행하였다. 후측파랑 추산자료의 정 확도를 확인하기 위해서 해양수산부에서 운영하는 전국파랑 관측자료 제공시스템의 품질관리된 울산부이와 울산신항 파 랑 관측자료를 이용하여 검증한 결과 유의파고 $\left(H_{s}\right)$, 주기 $\left(T_{p}\right)$, 파향이 유사한 경향을 나타냈으며, 상관성 분석에서도 결정 계수 $\left(R^{2}\right)$ 가 울산부이 위치에서 0.96 , 울산신항 파랑 관측위치 에서 0.95 로 나타나 후측파랑 추산자료의 재현성이 우수한 것 으로 분석되었다.

울산신항 남방파제 2-1공구 축조공사 시의 공사일지와 후 측파랑 추산자료를 이용하여 2015년 1월 1일부터 12월 31일 까지 수행한 지반개량공(DCM)을 대상으로 파랑에 의한 비 작업일수를 분석한 결과 43 일로 나타났으며, 본 연구에서 제 안하는 일별 작업한계 파랑조건을 적용하여 계산한 비작업일 수는 48 일로 산정되어 공사일지 분석결과와 5 일 차이가 발 생하는 것으로 나타났다. 하지만 차이가 발생한 5 일에 대한 공사일지 분석결과 2 일은 작업 도중 피항, 1 일은 작업대기 상 태, 1 일은 오전 작업, 오후 작업대기를 수행한 것으로 분석 되어 온전히 작업을 진행한 날은 거의 없는 것으로 나타났다. 한편, “항만건설공사 설계실무요령”에서 제안하고 있는 파랑 출현율에 의한 방법을 적용하여 비작업일수를 산정한 결과 35
일로 나타나 본 연구에서 제안하는 방법보다 약 13 일 작게 산정되는 것으로 검토되었다. 따라서 본 연구에서 제안하는 일별 작업제한 파랑조건을 적용한 방법의 정확도가 기존의 파 랑출현율에 의한 방법보다 정확도가 높은 것으로 판단된다.

최종적으로 본 연구에서 도출한 일별 작업제한 파랑조건에 의한 비작업일수 산정방법을 연구 대상지인 울산신항 남방파 제 2-1공구에 적용하였다. 최근 10 년 간의 후측파랑 추산자 료를 생성하고 지반개량공 $(\mathrm{DCM})$ 의 작업한계 파랑조건을 기 준으로 파랑에 의한 비작업일수를 산정한 결과 39일로 계산 되었다. 한편, “항만건설공사 설계실무요령”에서 제시한 파랑 출현율을 이용한 방법을 적용하여 산정한 비작업일수는 28 일 로 나타났다. 이는 본 연구에서 제안하는 일별 작업제한 파 랑조건을 적용한 방법에 비해서 11 일 작게 산정된 것이다.

향후, 본 연구에서 제안한 일별 작업제한 파랑조건을 적용 한 해상건설 비작업일수 산정방법의 적용성을 파악하기 위해 서 동해항을 대상으로 공사일지 수집·분석, 장기 후측파랑 추 산실험 등을 수행할 계획이다.

\section{References}

Choi, S.H., Back, J.D., Jeong, W.M. and Choi, H.J. (2019). A study on the estimation of the number of working days for harbor construction project considering wave condition. Journal of Korean Society of Coastal Disaster Prevention, 6(2), 71-82 (in Korean). Jeong, W.M., Oh, S.H., Ryu, K.H., Back, J.D. and Choi, I.H. (2018). Establishment of wave information network of korea (WINK). Journal of Korean Society of Coastal and Ocean Engineers, 30(6), 326-336 (in Korean).

Kim, G.H., Ryu, K.H. and Yoon, S.B. (2020). Numerical simulation of storm surge and wave due to typhoon bolaven of 2012. Journal of Korean Society of Coastal and Ocean Engineers, 32(4), 273-283 (in Korean).

Ministry of Oceans and Fisheries (2019). Report on the deep water design wave estimation in the Korea (in Korean).

Ministry of Oceans and Fisheries (2020), Report on the design practice for harbor construction project (in Korean).

Ro, H.Y. (1969). Problems on design and construction used heavy equipments. Journal of Korean Society of Civil Engineers, 17(1), 54-69 (in Korean).

Ulsan Regional Office of Oceans and Fisheries (2013). Detailed design report for construction of southern breakwater (Section 2-1) of Ulsan new port (in Korean).

Received 3 March, 2021

Revised 5 April, 2021

Accepted 20 April, 2021 